\title{
Effect of Cassava Whey on the Physicochemical Parameters and Heavy Metals Distribution in Soil
}

\author{
Segun Michael Abegunde ${ }^{1 *}$, Simeon Ajibade Akinyele ${ }^{1}$, Olatunde Isaac Awonyemi²
}

${ }^{I}$ Department of Science Technology, Federal Polytechnic, Ado-Ekiti, Ekiti State, Nigeria ${ }^{2}$ Central Research Laboratory, Federal University of Technology, Akure, Ondo State,Nigeria

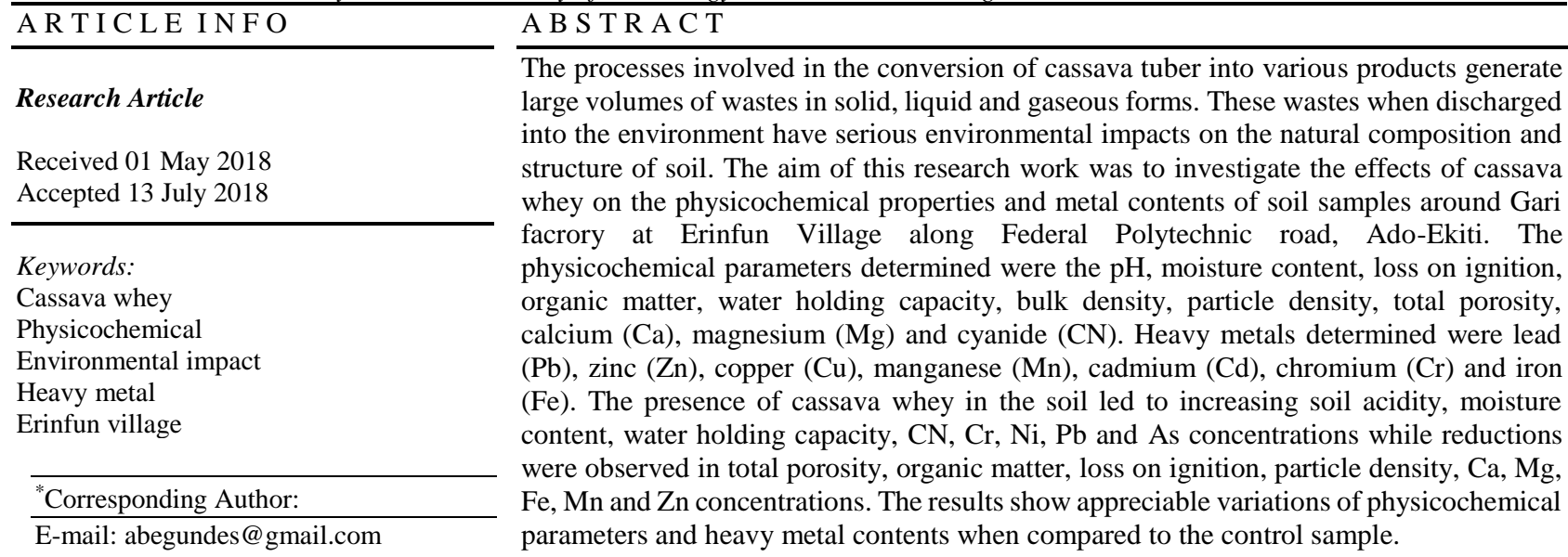

DOI: https://doi.org/10.24925/turjaf.v6i9.1196-1199.1995

\section{Introduction}

Increasing damages to natural soil as a result of various anthropogenic activities have become a great concern for environmentalists. The risk to human lives and aquatic organisms constituted by agriculture and wastes discharge cannot be over-stressed (Etinosa and Ozede, 2015). Most farming activities are responsible for releasing contaminants into the environment. The earth had become loaded with diverse pollutants that are released as agriculture by-products. The global environment is changing continuously due to unfavourable alteration of nature as a result of human activities which affect ecosystem either directly or indirectly (Abegunde et al., 2017). Chemicals are a major source of water and soil contaminations [ISI, 1983, Abegunde et al., 2017] that are introduced during washing of agricultural wastes such as decayed farm by-products, fertilizer, pesticide etc from the farmland. This act has a terrible impact on the natural composition and structure of the soil. Environmental pollution is undesirable changes in land, air and water as a result of over population, rapid industrialization and other human activities such as agriculture and deforestation [European Public Health Alliance, 2009]. Agricultural pollution has been a major environmental problem in Africa and it must be halted without delay before leading to disastrous health and irreversible environmental problem. The waste generation cannot be eliminated totally but an improved processing method, the reuse of the byproduct and improved waste disposal system will be of great economy value and as well as creating a safe environment.

Cassava is a major farm produce in many parts of Nigeria. Cassava products constitute a large part of food in Southern Nigeria for both man and animals. The ability of cassava to grow on any type of soil with less monitoring made it easy for farmers to venture into cassava farming. Cassava products are known for their readily availability in Nigerian market in various forms and are found to be the cheapest food items available. Cassava tuber is usually processed into different forms before getting to the consumers. It is processed into gari, lafu, fufu, bread, starch, ethanol among others. During the different stages of processing, cassava effluents and other wastes are discharged into the surrounding soil, air or water without any form of treatment (Iwegbue, 2013). Among others, two 
most important biological wastes that cause damage to the surrounding during cassava processing are the cassava peels and the liquid effluent squeezed out (Obueh and Odesiri-Eruteyan, 2016) during fermentation. Continuous act of discharging of this effluent into the surrounding soil for a long period of time without treatment leads to alteration in the natural composition and structural arrangement of soil components.

The aim of this present study is to investigate the effect of cassava whey on the physical, chemical and metallic properties of the soil around cassava factory, Erinfun Village, Ado-Ekiti.

\section{Materials and Methods}

\section{Study Area}

Cassava factory at Erifun village, along Federal Polytechnic, Ikare Road, Ado-Ekiti was considered for the present study. The village lying in latitude N 7³6'25.272' E $5^{\circ} 17^{\prime} 17.6928$ has a pollution density of less 2,500 inhabitant specializes mainly on vegetable and cassava farming. The average annual temperature of the area is $25.1^{\circ} \mathrm{C}$ and averages annual rainfall of $1334 \mathrm{~mm}$. The soil type is made up of ferrosol precisely the red and brown soil. Its main relief feature is regarded as lowland type of landscape categorized under coastal lowland of Western Nigeria within tropical rainforest region.

\section{Sample Collection and Treatment}

Three sets of soil samples were obtained. Soil samples were obtained $0 \mathrm{~cm}$ from the point of fermentation stand, Garri factory, Erinfun Village along Federal Polytechnic road, Ado-Ekiti, Ekiti state and labelled as sample A. Four soil samples were obtained from four different locations $200 \mathrm{~m}$ away from point of fermentation labelled sample $B_{1}$, $\mathrm{B}_{2}, \mathrm{~B}_{3}$ and $\mathrm{B}_{4}$ respectively while the control soil sample was taken at a location considered not affected by the pollutant and labelled C. All the samples were taken with soil auger at depth of $0-15 \mathrm{~cm}$. The soil samples from $0-$ $15 \mathrm{~cm}$ depth were taken for the analysis to represent top soil needed for most vegetable plants. The sampling was done in April, 2018. The samples in polythene bags were transported to the chemistry laboratory at Federal Polytechnic for analysis.

\section{Sample Preparation}

The soil samples were air-dried in the laboratory, gently crushed with mortar and pestle, passed through $2 \mathrm{~mm}$ polymer-mesh sieve, homogenized and stored in polythene bags. Samples $\mathrm{B}_{1}, \mathrm{~B}_{2}, \mathrm{~B}_{3}$ and $\mathrm{B}_{4}$ were mixed thoroughly and representative sample was taken from the bulk. Samples for metallic analysis were digested using aqua regia (mixture of hydrochloric acid and nitric acid in ratio 3:1). The digested samples were analysed for metals using Atomic Absorption Spectrophotometer (Buck Scientific Model210VGP) fitted with deuterium lamp for background correction.

Physicochemical parameters of the soil samples such as soil pH, Moisture content, Loss on Ignition, Water Holding Capacity, Total Porosity, Bulk Density, Particle Density, Organic Matter and Cyanide were determined using standard methods respectively (Davey and Conyers, 1998; Nelson and Sommers, 1982; Thomas, 1996; Bouyoucos,
1962; Bray and Kurtz, 1945; Bremner, 1945; Chopra and Kanzar, 1988).

All reagents used were of pure analytical grade. All glassware used were previously soaked with $14 \%$ nitric acid to remove stains of metals, washed with detergents and rinsed under running water and then with deionized water.

\section{Results and Discussion}

Table 1 showed the results of physicochemical parameters of the samples. The $\mathrm{pH}$ of the soil samples showed that the samples are acidic. Sample A is the most acidic and the control sample with the least. The acidic level decreases with increase in the distance of sample location from the discharged point. This indicates that the cassava effluent imparted acidic properties to the soil samples. The acidity property observed in the contaminated samples could be as a result of the presence of hydrogen cyanide in the cassava whey (Thomas, 1996). Highest moisture content was observed in sample A with decrease in the moisture content with increase in the distance away from the source of cassava whey. The highest water holding capacity was recorded for sample A with the control sample having the least. Soil sample with higher water holding capacity is required for its ability to retain much nutrients needed for plant growth but could be dangerous to plants because soil with excessive water holding capacity tend to be poorly aerated and limit the amount of soil oxygen which affect activities of useful microorganisms required to convert the retained nutrient to forms needed by plants. Other physicochemical parameters that increase with distance from the point of discharge of pollutant are total porosity, loss on ignition, calcium content and organic matter. Total porosity and water holding capacity of soil have an inversely proportional relation which was clearly observed in the soil samples considered. The table also showed that sample A has the least organic matter. Organic matter has both a direct and indirect effects on the nutrients availability for plant growth (Mc Carthy, 1990). Low organic matter indicates low humus in the soil. Humus has an intense effect on the structure of soils. The damages in soil structure that follows continuous release of cassava whey leading to low microbial activities as a result of low soil aeration and less permeability are all favourably affect humus thereby soil tend to become hard and compact when dried and cloddy (Stevenson, 1972) when wet. For calcium, the distribution of calcium in the soil samples might be as a result of acidic properties of the soil samples caused by constant release of cassava whey containing cyanide. Calcium content is less and less reactive in acid soils. The magnesium content was significantly lower in the sample A than in samples B and C. This may be as a result of high level of hydrogen cyanide in the contaminated soil (Uzochukwu et al., 2001). The Hydrogen cyanide in the cassava effluent is transferred and remains in soil when discharged. This is dangerous to plant health because it reduces the soil quality. This results to the decrease in soil $\mathrm{pH}$ (promote soil acidity), magnesium and calcium while cyanide, phosphate and sulphate contents will be on the increase (Eze and Onyilide, 2015). Particle density of the samples decreases with increase distance from point of discharge of cassava whey. No significant 
difference in the bulk densities observed in the samples and control sample. As expected, highest $\mathrm{CN}$ level was recorded for sample from the point of discharge of the contaminant with the control having the least. The result of statistical analyses as presented in Table 1 shows that there are significant differences in the values of each physicochemical parameter computed for the samples.

Table 2 showed the results of heavy metals in the soil samples. The heavy metals analysed for are $\mathrm{Fe}, \mathrm{Pb}, \mathrm{Mn}$, $\mathrm{Cd}, \mathrm{Ni}, \mathrm{Cr}, \mathrm{As}, \mathrm{Cu}$ and $\mathrm{Zn}$. The results of heavy metal analysis also showed variations when compared with the control sample. Highest contents of $\mathrm{Ni}, \mathrm{Cr}$ and As were recorded for sample A with the decrease in each of the metals contents of the samples as distance from the point of discharge of the contaminant increases. Contaminated soil samples have the lower values of $\mathrm{Fe}, \mathrm{Mn}$ and $\mathrm{Zn}$ with highest values observed in the control sample. Also, analysis of variance gave an indication that there are significant differences in the values recorded for each metal in the samples.

Table 3 present the result of Pearson correlation coefficient. Fe and $\mathrm{Mn}, \mathrm{Fe}$ and $\mathrm{Zn}, \mathrm{Mn}$ and $\mathrm{Zn}, \mathrm{Cr}$ and $\mathrm{Ni}$ and $\mathrm{Cd}$ and $\mathrm{Cu}$ are strongly and positively correlated while $\mathrm{Ni}$ and As show moderate and positive correlation. This shows that both metals in each category accumulate and move together in the soil samples.

Table 1 Descriptive statistical of variation of physicochemical properties of the soil samples

\begin{tabular}{|c|c|c|c|c|c|c|c|c|c|c|c|c|}
\hline $\mathrm{S}$ & & $\mathrm{pH}$ & $\begin{array}{l}\mathrm{MC} \\
(\%) \\
\end{array}$ & WHC & $\begin{array}{c}\mathrm{TP} \\
(\%)\end{array}$ & $\begin{array}{l}\text { OM } \\
(\%) \\
\end{array}$ & $\begin{array}{c}\text { LI } \\
(\%) \\
\end{array}$ & $\mathrm{BD}$ & DP & $\begin{array}{c}\mathrm{Ca} \\
(\mathrm{mg} / \mathrm{kg})\end{array}$ & $\begin{array}{c}\mathrm{Mg} \\
(\mathrm{mg} / \mathrm{kg})\end{array}$ & $\begin{array}{c}\mathrm{CN} \\
(\mathrm{mg} / 100 \mathrm{ML}) \\
\end{array}$ \\
\hline \multirow{4}{*}{ A } & $\mathrm{M}$ & $6.130^{c}$ & $0.843^{\mathrm{c}}$ & $15.967^{\mathrm{c}}$ & $53.443^{c}$ & $24.377^{\mathrm{c}}$ & $1.057^{\mathrm{c}}$ & $0.943 b$ & $2.153^{\mathrm{b}}$ & $0.260^{\mathrm{c}}$ & $0.220^{\mathrm{a}}$ & $0.038^{\mathrm{a}}$ \\
\hline & STD & 0.010 & 0.006 & 0.252 & 0.140 & 0.119 & 0.051 & 0.038 & 0.050 & 0.017 & 0.000 & 0.001 \\
\hline & Min & 6.120 & 0.840 & 15.700 & 53.330 & 24.280 & 1.000 & 0.900 & 2.100 & 0.240 & 0.220 & 0.037 \\
\hline & Max & 6.140 & 0.850 & 16.200 & 53.600 & 24.510 & 1.100 & 0.970 & 2.200 & 0.270 & 0.220 & 0.038 \\
\hline \multirow{4}{*}{ B } & Mean & $6.553^{\mathrm{b}}$ & $0.647^{\mathrm{b}}$ & $12.300^{\mathrm{b}}$ & $54.733^{b}$ & $26.667^{b}$ & $1.187^{\mathrm{b}}$ & $1.133 \mathrm{ab}$ & $2.180^{\mathrm{b}}$ & $0.773^{\mathrm{b}}$ & $0.283^{b}$ & $0.020^{\mathrm{b}}$ \\
\hline & STD & 0.006 & 0.021 & 0.100 & 0.208 & 0.351 & 0.012 & 0.115 & 0.072 & 0.012 & 0.006 & 0.000 \\
\hline & Min & 6.550 & 0.630 & 12.200 & 54.500 & 26.300 & 1.180 & 1.000 & 2.100 & 0.760 & 0.280 & .02000 \\
\hline & Max & 6.560 & 0.670 & 12.400 & 54.900 & 27.000 & 1.200 & 1.200 & 2.240 & 0.780 & 0.290 & 0.020 \\
\hline \multirow{4}{*}{$\mathrm{C}$} & Mean & $6.797^{\mathrm{a}}$ & $0.403^{\mathrm{a}}$ & $10.167^{\mathrm{a}}$ & $58.600^{\mathrm{a}}$ & $44.300^{\mathrm{a}}$ & $1.483^{\mathrm{a}}$ & $0.977 \mathrm{a}$ & $2.350^{\mathrm{a}}$ & $0.837^{\mathrm{a}}$ & $0.300^{\mathrm{a}}$ & $0.009^{c}$ \\
\hline & STD & 0.0153 & 0.0153 & 0.252 & 0.173 & 0.529 & 0.040 & 0.006 & 0.050 & 0.012 & 0.000 & 0.001 \\
\hline & Min & 6.780 & 0.390 & 9.900 & 58.400 & 43.900 & 1.440 & 0.970 & 2.300 & 0.830 & 0.300 & 0.008 \\
\hline & Max & 6.810 & 0.420 & 10.400 & 58.700 & 44.900 & 1.520 & 0.980 & 2.400 & 0.850 & 0.300 & 0.009 \\
\hline
\end{tabular}

S: Sample, M: Mean, Mean represents an average of triplicate determinations. Within each column, means that do not share a letter are significantly different. $\mathrm{MC}=$ Moisture content, $\mathrm{WHC}=$ water holding capacity, $\mathrm{TP}=$ total porosity, $\mathrm{OM}=$ organic matter, $\mathrm{LI}=$ loss on ignition, $\mathrm{BD}=$ bulk density, $\mathrm{DP}=$ particle density,

Table 2 Descriptive statistics of heavy metals distribution in the soil samples

\begin{tabular}{l|lccccccccc}
\hline \multicolumn{1}{c}{ Metal } & & $\mathrm{Fe}$ & $\mathrm{Mn}$ & $\mathrm{Cr}$ & $\mathrm{Ni}$ & $\mathrm{Pb}$ & $\mathrm{Zn}$ & $\mathrm{Cd}$ & $\mathrm{As}$ & $\mathrm{Cu}$ \\
\hline & Mean & $6.200^{\mathrm{c}}$ & $0.170^{\mathrm{c}}$ & $0.0100^{\mathrm{b}}$ & $0.0040^{\mathrm{b}}$ & $0.0300^{\mathrm{c}}$ & $0.2600^{\mathrm{c}}$ & $0.0010^{\mathrm{b}}$ & $0.0004^{\mathrm{b}}$ & $0.0100^{\mathrm{a}}$ \\
Sample A & STD & 0.1000 & 0.0200 & 0.00000 & 0.0010 & 0.0000 & 0.0173 & 0.0000 & 0.0001 & 0.0000 \\
$(\mathrm{mg} / \mathrm{kg})$ & Min & 6.1000 & 0.1500 & 0.1000 & 0.0030 & 0.0300 & 0.2400 & 0.0010 & 0.0003 & 0.0100 \\
& Max & 6.3000 & 0.1900 & 0.0100 & 0.0050 & 0.0300 & 0.2700 & 0.0010 & 0.0005 & 0.0100 \\
\hline & Mean & $8.2200^{\mathrm{b}}$ & $0.3200^{\mathrm{b}}$ & $0.0093^{\mathrm{a}}$ & $0.0030^{\mathrm{a}}$ & $0.0060^{\mathrm{b}}$ & $0.3900^{\mathrm{b}}$ & $0.0060^{\mathrm{b}}$ & $0.0001^{\mathrm{b}}$ & $0.0200^{\mathrm{a}}$ \\
Sample B & STD & 0.0265 & 0.0173 & 0.0012 & 0.0000 & 0.0010 & 0.0100 & 0.0010 & 0.0000 & 0.0000 \\
$(\mathrm{mg} / \mathrm{kg})$ & Min & 8.2200 & 0.3000 & 0.0080 & 0.0030 & 0.0050 & 0.3800 & 0.0050 & 0.0001 & 0.0200 \\
& Max & 8.2400 & 0.3300 & 0.0100 & 0.0030 & 0.0070 & 0.4000 & 0.0070 & 0.0001 & 0.0200 \\
\hline & Mean & $12.6400^{\mathrm{a}}$ & $0.6200^{\mathrm{a}}$ & $0.0003^{\mathrm{a}}$ & $0.0010^{\mathrm{a}}$ & $0.0400^{\mathrm{a}}$ & $0.5200^{\mathrm{a}}$ & $0.0001^{\mathrm{a}}$ & $0.0001^{\mathrm{a}}$ & $0.0100^{\mathrm{a}}$ \\
Sample C & STD & 0.2433 & 0.0200 & 0.0000 & 0.0000 & 0.0000 & 0.0100 & 0.0000 & 0.0000 & 0.0000 \\
$(\mathrm{mg} / \mathrm{kg})$ & Min & 12.6400 & 0.6000 & 0.0003 & 0.0010 & 0.0400 & 0.5100 & 0.0001 & 0.0001 & 0.0100 \\
& Max & 12.8000 & 0.6400 & 0.0003 & 0.0010 & 0.0400 & 0.5300 & 0.0001 & 0.0001 & 0.0100 \\
\hline
\end{tabular}

Mean represents an average of triplicate determinations. Within each column, means that do not share a letter are significantly different.

Table 3 The Pearson correlation coefficient between metals concentrations in the samples

\begin{tabular}{l|cccccccc}
\hline & $\mathrm{Fe}$ & $\mathrm{Mn}$ & $\mathrm{Cr}$ & $\mathrm{Ni}$ & $\mathrm{Pb}$ & $\mathrm{Zn}$ & $\mathrm{Cd}$ & $\mathrm{As}$ \\
\hline $\mathrm{Fe}$ & 1 & & & & & & & \\
$\mathrm{Mn}$ & $0.998^{* *}$ & 1 & & & & & & \\
$\mathrm{Cr}$ & $-0.961^{* *}$ & $-0.955^{* *}$ & 1 & & & & & \\
$\mathrm{Ni}$ & $-0.931^{* *}$ & $-0.923^{* *}$ & $0.894^{* *}$ & 1 & & & & \\
$\mathrm{~Pb}$ & 0.481 & 0.460 & $-0.681^{*}$ & -0.432 & 1 & & & \\
$\mathrm{Zn}$ & $0.970^{* *}$ & $0.970^{* *}$ & $-0.884^{* *}$ & $-0.938^{* *}$ & 0.285 & 1 & & 1 \\
$\mathrm{Cd}$ & -0.285 & -0.270 & 0.525 & 0.247 & $-0.964^{* *}$ & -0.076 & 1 & -0.286 \\
$\mathrm{As}$ & $-0.792^{*}$ & $-0.811^{* *}$ & 0.624 & $0.696^{*}$ & 0.096 & $-0.861^{* *}$ & -0.286 & 1 \\
$\mathrm{Cu}$ & -0.210 & -0.188 & 0.442 & 0.177 & $-0.958^{* *}$ & 0.000 & $0.979^{* *}$ & -0.365 \\
\hline
\end{tabular}

**. Correlation is significant at the 0.01 level (2-tailed), *. Correlation is significant at the 0.05 level (2-tailed). 
Fe and $\mathrm{Cr}$, Fe and $\mathrm{Ni}, \mathrm{Mn}$ and $\mathrm{Cr}, \mathrm{Mn}$ and $\mathrm{Ni}, \mathrm{Mn}$ and $\mathrm{As}, \mathrm{Cr}$ and $\mathrm{Pb}, \mathrm{Cr}$ and $\mathrm{Zn}, \mathrm{Ni}$ and $\mathrm{Zn}, \mathrm{Pb}$ and $\mathrm{Cd}, \mathrm{Pb}$ and $\mathrm{Cu}, \mathrm{Zn}$ and As are strongly but negatively correlated while $\mathrm{Fe}$ and As show moderate but negative correlation with each other. This implies that the presence of a metal reduces the accumulation or presence of the other in the pair.

\section{Conclusion}

This study has shown that cassava whey has serious effect on the physicochemical properties, metallic distribution and the natural arrangement of soil components. Cassava whey decreases soil $\mathrm{pH}$, porosity, organic matter, loss on ignition, particle density, calcium and magnesium contents while it leads to higher levels of water holding capacity, moisture content and cyanide content in the affected soil samples. The results of heavy metals analyzed showed elevated levels of $\mathrm{Ni}, \mathrm{Cr}$, and $\mathrm{As}$ in the soils polluted by cassava whey and showed lower level of Fe, Mn and Zn. Generally, the study revealed that indiscriminately discharged of cassava whey into the environment cause noticeable changes in the availability and distribution of metals and physicochemical properties of the soils. There is urgent need to develop, introduce and follow up treatment methods to reduce the potential environmental hazards of this cassava waste before discharge onto agricultural lands.

\section{References}

Abegunde SM, Adejuwon OM, Olorunfemi TO. 2017. Safety Assessment of Hand-Dug Well Water Samples from Selected Towns in Ekiti State, Nigeria. Journal of Advanced Research In Applied Chemistry \& Chemical Engineering, 4(1\&2). Retrieved from http://science.adrpublications.in/index.php/ JoARACCE/article/view/351

Bouyoucos GJ. 1962. Improved hydrometer method for making particle size analysis, Agron. J., 54: 464-465

Bray RH, Kurtz LT. 1945. Determination of Total organic and available forms of phosphorus in soils, Soil Sci., 59: 30-45
Bremner JM. 1945. Total nitrogen. In: Black C.A. (ed) Methods of soil analysis part 2, Agron., 9: 149-178

Chopra G, Kanzar C, Analytical Agricultural Chemistry, 2nd Edition Prentice- Hall, India

Davey BG, Conyers MK. 1988. Determining the $\mathrm{pH}$ of acid soils, Soil Sci., 146: 141-150

European Public Health Alliance. 2009. Air, Water Pollution and Health Effects. Retrieved from http://www.epha.org/r/54.

Etinosa OI, Ozede NI. 2015. The Impact of Cassava Effluent on the Microbial and Physicochemical Characteristics on Soil Dynamics and Structure, Jordan Journal of Biological Sciences. 8(2): 107-112.

Eze VC, Onyilide DM. 2015. Microbiological and physicochemical characteristics of soil receiving cassava effluent in Elele, Rivers State, Nigeria. J Appl Environ Microbiol 3: 20-24.

ISI. 1983. India standard specification for drinking water, New Delhi.

Iwegbue CMA, Bassey FI, Tesi GO, Nwajei GE, Tsafe AI. 2013 Assessment of Heavy Metal Contamination in Soils around Cassava Processing Mills in Sub-Urban Areas of Delta State, Southern Nigeria. Nigerian Journal of Basic and Applied Science, 21(2): 96-104 DOI: http://dx.doi.org/10.4314/ njbas.v21i2.2

Mc Carthy P, Malcolm RL, Clapp CE, Bloom PR. 1990. An introduction to soil humic substances, Humic substances in soil and crop sciences: selected readings, W: American Society of Agronomy, Soil Science of America. Madison, 112.

Nelson DW, Sommers LE. 1982. Total Carbon, Organic Carbon and organic matter, 539-579, In Page, A.Z et al.,(ed) Method of soil analysis

Obueh HO, Odesiri-Eruteyan E. 2016. A Study on the Effects of Cassava Processing Wastes on the Soil Environment of a Local Cassava Mill. J Pollut Eff Cont 4: 177. doi: 10.4176/2375-4397.1000177

Stevenson FJ. 1972. Role and Function of Humus in Soil with Emphasis on Adsorption of Herbicides and Chelation of Micronutrients. BioScience

Thomas GW. 1996. Methods of soil analysis, chemical methods SSA book series No.8 USA

Uzochukwu S, Oyede RA, Ayanda O. 2001. Utilization of garri industry effluent. Nigerian J Microbiol, 15: 87-92 